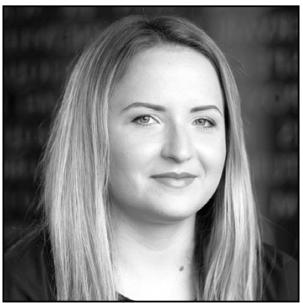

Maris Vutt

\title{
Digital Opportunities for - and Legal Impediments to - Participation in a General Meeting of Shareholders
}

\section{Introduction}

In conditions of a globalising economy, holding a meeting by electronic means of communication to arrange a company's daily economic activities is increasingly widespread. The reasons given for this include, for example, the fact that often people engaged in joint business are located remotely from each other, so, at least for some of them, meeting at the same time in the same place would be time-consuming and costly. It has also been found that physical participation may be impeded by certain natural circumstances, such as the risk of spread of diseases or weather conditions adverse to travel. ${ }^{{ }^{2}}$ The same impediments and inconveniences apply to public limited companies, whose shareholders are often located in different countries, such that physical attendance at a general meeting may prove to be excessively burdensome.

An expert group established by the European Commission has noted that the general meeting of shareholders as the highest body of a public limited company was originally created to ensure effective communication between the company and its shareholders. However, thanks to the virtually costless nature of digital communication, the rules for participation in a general meeting and the role of the general meeting should be reviewed. ${ }^{*}$ The expert group's analysis produced the conclusion that it is evident that no need exists to gather shareholders in one single physical location to hold a general meeting, and companies should allow shareholders to communicate even before, as well as during, the general meeting by ensuring availability of digital platforms for that purpose. ${ }^{*}$

Also, the company law review carried out by the Estonian Ministry of Justice found that, even though decision-making at a meeting presumes shareholders' personal presence, or at least presence by proxy, under the current law presence should not mean only physical presence of shareholders in the same place,

This article is based on laws as of 29 June 2020.

2 P Pullan, 'The Seven Secrets of Successful Virtual Meetings', paper presented at PMI Global Congress 2011 - EMEA, Dublin, Ireland (Newtown Square, PA, Project Management Institute). https://www.pmi.org/learning/library/successful-virtualmeetings-skills-improvement-6267.

3 The Informal Company Law Expert Group (ICLEG), 'Report on Digitalisation in Company Law (March 2016) para 22.1. https://ec.europa.eu/info/sites/info/files/icleg-report-on-digitalisation-24-march-2016_en.pdf.

$4 \quad$ Ibid, para 22.4. 
so that participation in a general meeting through virtual channels too is allowed if an adequate temporalspatial connection for participants is ensured. It is important that the law ensure not only the possibility to vote on draft resolutions by electronic means prior to a meeting but also the possibility to participate in a meeting through real-time transmission and to vote during the meeting. ${ }^{*}$

The present article analyses whether and to what extent Estonia and other countries (first and foremost, Germany as a country with a legal system similar to Estonia's, but also the Netherlands and the United Kingdom) regulate holding general meetings of public limited companies by electronic means, the requirements for virtual meetings, and legal problems related to electronic meetings. For this, the author relies on the hypothesis that electronic participation should not be impeded if shareholders are ensured all the rights related to participation in a general meeting that they would have when participating in a meeting physically. ${ }^{* 6}$

The public limited company as an open limited company was chosen as the object of study because, presumably, it is precisely the larger companies that need to ensure flexibility of meetings, whereas private limited companies, with a smaller 'membership', can probably, at least as a rule, arrange adoption of resolutions more flexibly. ${ }^{*} 7$

As of 24 May 2020, the Estonian Commercial Code $^{* 8}$ regulates electronic participation for public and private limited companies. Prior to that, electronic participation was allowed only for listed public companies. Legal literature notes that, in comparison to ordinary public limited companies, listed companies are subject to stricter requirements, arising primarily from the need to ensure the transparency of their activities, their credibility, and equal treatment of their investors. ${ }^{*}$ It has been found also that the larger the company, the more important the formal requirements become. ${ }^{*} 10$ The main reason for changing the regulation was that on 12 March 2020, the Estonian Government declared a state of emergency in connection with the global novel coronavirus pandemic. Therefore, the Ministry of Justice prepared a draft law that included regulations expanding the possibilities for digital meetings. ${ }^{*} 11$

\section{The legal significance of the general meeting of a public limited company and legal regulation of electronic participation}

\subsection{The legal significance of a general meeting}

Shareholders exercise their rights at a general meeting. On one hand, legal scholars have found that the legal status of shareholders as investors should afford them the opportunity to have a say in essential issues of company management, ${ }^{*} 2$ while, on the other hand, it has also been noted that, overall, the general meeting is the only place where shareholders can exercise their rights. ${ }^{*} 3$ At least under the Germanic company

\footnotetext{
Ministry of Justice, Ühinguõiguse revisjoni analüüs-kontseptsioon (The Analysis-Concept of Company Law Review) (Tallinn 2018) 538.

6 Although participation in a meeting is linked to electronic voting also, the article does not explore issues of electronic voting more closely, as this would require a separate analysis.

7 For example, shareholders of a private limited company may adopt resolutions in a format reproducible in writing (Commercial Code, s 173). As for electronic holding of meetings of shareholders of a private limited company, the law currently only addresses electronic voting (Commercial Code, s 170').

8 Commercial Code (Äriseadustik). RT I, 23 May 2020, 9.

9 K Saare, U Volens, A Vutt, and M Vutt, Ühinguõigus I. Kapitaliühingud (Company Law I: Limited Companies) (Tallinn: Juura 2015) margin reference 1670.

10 E Boros, 'Virtual Shareholder Meetings' [2004] 8 Duke Law and Technology Review 6.

11 Draft Act Amending the General Part of the Civil Code Act and Other Acts (Expanding Electronic Capabilities for Meetings and Decision-Making), 6 April 2020 (Tsiviilseadustiku üldosa seaduse ja teiste seaduste muutmise seadus. Eelnõu 6.04.2020). http://eelnoud.valitsus.ee/main/mount/docList/ab3f09b7-7557-48e9-bb29-38fa178faa9a?fbclid=IwAR24sbJOifRkLwEJQyM-SjpoOlklgW-BHjOFKXgUzQFE4q3Pp6NzZfZG4mU\#spQpVxw5.

12 M Vutt, 'Aktsionäri derivatiivnõue kui õiguskaitsevahend ja ühingujuhtimise abinõu' (A Shareholder's Derivative Claim As a Legal Remedy and a Measure of Corporate Governance) (PhD thesis, University of Tartu, 2011) 44.

13 K Saare, U Volens, A Vutt, and M Vutt (n 9) margin reference 1670.
} 
law model, the competence of the general meeting is not unlimited, while at the same time more essential issues fall precisely within the competence of shareholders. ${ }^{*}{ }^{14}$

The general meeting of shareholders deals primarily with adopting resolutions, but decision-making is far from the only function of the general meeting of a public limited company. At least equally important is that shareholders receive information at a general meeting (inter alia, under \$287(1) of the Commercial Code, each individual shareholder is entitled to receive information from the management board at the general meeting). In German legal literature, it has been noted that the most important function of a general meeting is to articulate the will of the majority of participating shareholders at the meeting and, through resolutions adopted at the meeting, act as one of the company's bodies in relations with other bodies. ${ }^{* 15} \mathrm{Ger}-$ man legal literature also considers the shareholders' rights related to participation at the meeting to include the right to information, the right to have a say, the right to submit proposals and drafts, and the right to object to a resolution. ${ }^{* 16}$ Dutch legal literature emphasises that the most important aspect of a general meeting is the opportunity for communication between the shareholders and the management board. ${ }^{*} 17$

At the same time, the legal literature expresses the view that, at least in the case of large listed companies, the actual effect and effectiveness of general meetings of shareholders is questionable since shareholders are passive and since institutional investors prefer to communicate directly with the management board and not at a general meeting, while for the rest of the shareholders attendance at a general meeting is simply inconvenient in terms of both time and space as meetings take place during working hours and mostly far from the shareholder's residence. ${ }^{*} 18$ These problems could at least partially be resolved by a virtual general meeting.

\subsection{Legal regulation of participation in a virtual general meeting}

For a long time, a tacit presumption applied in company law that the idea of a general meeting is that all shareholders convene at the same time in the same place, so public limited companies could hold a general meeting only at the company's registered office (or another designated place) and only those shareholders physically present were deemed to be in attendance. Under \$290(1) of the Commercial Code, shareholders exercise their rights in a public limited company at the general meeting of shareholders, which under \$295 is to be held at the registered office of the public limited company unless otherwise prescribed by the articles of association. ${ }^{*}{ }^{19}$ In 2009, special provisions for listed companies were introduced to the Commercial Code. Under $\S 290^{1}$ of the version in effect since then, a listed company may prescribe in its articles of association that the shareholders may participate in the general meeting and exercise their rights by electronic means without physically attending the general meeting and without appointing a representative, if this is possible in a technically secure manner. ${ }^{* 20}$ Section $290^{1}(1)$, clause 1 of the Commercial Code lays down terms for participation in a general meeting by means of real-time two-way communication throughout the general meeting or by other, similar electronic means that enable the shareholder to observe the general meeting from a remote location, vote by using electronic means throughout the general meeting on each draft resolution, and address the general meeting at the time determined by the chair of the meeting. ${ }^{* 1}$ Section $290^{1}$

14 For example, §298(1) of the Commercial Code lists the issues within the competence of the general meeting and subsection (2) of the same section lays down that a general meeting may adopt resolutions on other matters related to the activities of a public limited company at the request of the management board or supervisory board. In principle, this is similar to $§ 119$ of the German AktG, the first subsection of which lists the competencies of the general meeting and the second subsection of which states that the general meeting may decide on matters pertaining to the day-to-day management of the company only if requested by the management board or the supervisory board.

15 T Drygala, M Staake, and S Szalai, Kapitalgesellschaftsrecht. Mit Grundzügen des Konzern- und Umwandlungsrechts (Springer: Heidelberg, Dordrecht, London, New York 2012) 470.

16 U Hüffer and J Koch, Beck'scher Kurz-Kommentare, vol 53. Aktiengesetz (13th edn, Verlag C.H. Beck München 2018) Koch, 'AktG', s 118, margin reference 12.

17 A van der Krans, 'The Virtual Shareholders' Meeting: How To Make It Work' [2007] Journal of International Commercial Law and Technology 32.

18 E Boros (n 10) 3-4.

19 With regard to this provision, the articles of association may only prescribe that a general meeting be held through physical participation but at an address different from the company's registered office. Probably the term 'registered office' cannot be interpreted to refer to the online environment.

20 The law does not define more specifically what is to be understood as technically secure.

21 According to the explanatory memorandum to the Draft Act Amending the Commercial Code, the list of opportunities for holding an electronic meeting is open and a listed company in its articles of association may also lay down ways of holding a 
was introduced to the Commercial Code in connection with transposing the Shareholder Rights Directive ${ }^{*_{22}}$ into Estonian law. It is important to emphasise that if a listed company wishes to enable electronic participation for its shareholders, this must be laid down in the articles of association. Under the current law, this is not a default possibility arising directly from the law. ${ }^{{ } 23}$

On 24 May 2020, new regulation entered into force, which allows electronic participation also for nonlisted public companies. Prior to the new regulation, a possibility to regulate holding a meeting through electronic means of communication in the articles of association was not clearly prescribed. Therefore, legal literature concluded that the admissibility of such provisions in articles of association is debatable. It had already been found that, at least to a certain extent, there could be freedom to shape the rules pertaining to relations between a public limited company and its shareholders in the articles of association (at least to the extent that no essential shareholder rights are violated). ${ }^{* 24}$ On the other hand, the view has been expressed that the rules on public limited companies are mandatory, at least to a larger extent, and deviations from the provisions of the law are possible only where explicitly so provided by law. ${ }^{* 25}$ Furthermore, Estonian legal scholars expressed a strong view that the law did not actually exclude the possibility of holding virtual meetings even before the new regulation was introduced in Estonia. ${ }^{*} 6$

One of the aims set out in the terms of reference for review of Estonian company law was to promote the holding of electronic meetings. ${ }^{* 27}$ The draft act amending the Commercial Code ${ }^{*} 28$ prepared in the course of the review was intended to introduce regulation to it that is, aimed, inter alia, at regulating the holding of a general meeting through a special voting platform set up in connection with the commercial register. However, taking into account the latest developments and the urgent need for regulating virtual meetings, the author is of the opinion that this proposal would not have been as quickly implemented and flexible as needed and therefore could only have been considered as an additional option.

As noted above, in connection with the ongoing pandemic, the law that entered into force on 24 May 2020 is designed to grant an opportunity to hold digital meetings for all types of legal bodies in private law, whether the articles of association foresee this option or not. As a result, the General Part of the Civil Code Act ${ }^{* 29}$ was supplemented with a provision according to which every member of a body of a legal person may attend the meeting of the body and exercise their rights without being physically present, by an electronic mechanism that allows the member to observe the meeting, to speak, and to vote, unless the articles of association provide otherwise. The new regulation also includes terms whereby the procedures specified in the articles of association or by the management board for holding of electronic meetings must ensure the security and reliability of the identification of shareholders and shall be proportionate to the achievement of those objectives.

meeting not included in the list. See: SE 467, 'Explanatory Memorandum to the Draft Act Amending the Commercial Code'. https://www.riigikogu.ee/tegevus/eelnoud/eelnou/041369ed-82db-4840-cb2a-28eb744989d2/\%C3\%84riseadustiku\%20 ja\%20teiste\%20seaduste\%20muutmise\%20seadus.

22 Directive 2007/36/EC of the European Parliament and of the Council of 11 July 2007 on the exercise of certain rights of shareholders in listed companies [2007] OJ L 184, 17-24. The above directive was revised in 2017 but the general principles have remained the same (see: Directive (EU) 2017/828 of the European Parliament and of the Council of 17 May 2017 amending Directive 2007/36/EC as regards the encouragement of long-term shareholder engagement (text with EEA relevance) [2017] OJ L 132, 1-25.

23 In this regard, it should be noted that analysis of the articles of association of some Estonian listed companies shows that some listed companies have not regulated electronic participation in their articles of association (e.g., Tallinna Kaubamaja Grupp AS, AS Merko Ehitus), while others provide for electronic participation in their articles of association (e.g., AS LHV Group) but confine the reference generally to copying provisions of the law.

24 K Saare, U Volens, A Vutt, and M Vutt (n 9) margin reference 1721-25.

25 See, for example: P Varul et alia., Võlaõigusseadus I. Kommenteeritud väljaanne (Law of Obligations Act, Annotated Edition) (Tallinn: Juura 2016) - P Varul, s 5, comment 3.

26 U Volens and A Vutt. ‘Õigusteadlased: digitaalse koosoleku võrdsustamisest füüsilise koosolekuga' (Legal Scholars: Equalising a Digital Meeting with a Physical Meeting). https://www.err.ee/1074990/oigusteadlased-digitaalse-koosoleku-vordsustamisest-fuusilise-koosolekuga.

27 Ministry of Justice (n 5) 26.

28 The Draft Act Amending the Commercial Code. See the material on the initial project for debate by the company law working group, of 14 October 2019, available online at: https://www.just.ee/sites/www.just.ee/files/ariseadustiku_eelnou_17.10.2019.pdf.

29 General Part of the Civil Code Act (Tsiviilseadustiku üldosa seadus). - RT I, 06.12.2018, 3. 
According to the explanatory memorandum to the draft law, ${ }^{*}{ }^{30}$ and as of the entry into force of the regulation, this amendment is not a temporary measure. Therefore, it will stay in force even when the state of emergency is declared to have ended.

Germany, on the other hand, has chosen a different legal approach to holding digital meetings in the era of social distancing. Namely, on 27 March 2020, its Act to Mitigate the Consequences of the COVID-19 Pandemic under Civil, Insolvency and Criminal Procedure Law (COVInsAG) was adopted. ${ }^{*}{ }^{31}$ It includes some temporary rules regarding virtual general meetings of public companies. Article 2, Section 1(2) of the COVInsAG grants the management board the right to decide that the general meeting is to be held virtually, provided that the broadcast of the meeting encompasses the entire meeting and that shareholders have an opportunity to exercise their voting right and are given the opportunity to ask questions and to object to resolutions. Also, the management board is granted the right to decide that the members of the supervisory board may participate at the general meeting by means of audio and video transmission. ${ }^{*}{ }^{32}$ As is stated in Article 2, Section 7(2), the above-mentioned rules apply only to shareholder meetings held and resolutions passed in 2020. Article 6(2) foresees these temporary rules ceasing to have effect at the end of 31 December 2021.

As the above-mentioned changes in German legislation are not fundamental and are more of a temporary nature, one must also study the legal regulation of digital meetings under Germany's regular law. The main difference is that normal German law already lays down the right of electronic participation for nonlisted public companies but it still has to be foreseen in the articles of association of the relevant company. In line with the first sentence of \$118(1) of the Aktiengesetz ${ }^{*} 3$ (AktG), shareholders exercise their rights in a public limited company at a general meeting unless said act prescribes otherwise. According to the second sentence of the same subsection, the articles of association may allow the shareholders to participate in the meeting without being present on the site and without sending a proxy-holder, and they may exercise any group or individual rights by way of electronic means of communication. The articles of association can also authorise the management board to decide on the opportunity for electronic participation in the meeting.

Section 118(3) of the AktG also lays down an important principle: the members of the management board and the supervisory board (unlike shareholders) must attend the general meeting directly, and only the articles of association may allow for certain cases wherein the attendance of supervisory board and management board members may be either by video or by audio transmission. Under \$118(4) of the AktG, the articles of association or the bylaws (Geschäftsordnung) may allow audio-visual transmission of the general meeting. The articles of association may also authorise the management board or the chair of the general meeting to decide on transmission of the general meeting. Legal literature notes with regard to these provisions that the legislator has empowered the shareholders, through the articles of association, to decide on the matter of whether holding a meeting through electronic means of communication is in principle possible in a particular company. Under regular law, outside the rules of the articles of association, the management board itself is not entitled to decide whether to hold a meeting electronically versus traditionally. ${ }^{*} 34$

Section 118(4) of the AktG - i.e., the regulation allowing either video or audio transmission of a meeting - also entails enabling passive exercise of shareholder rights. However, the second sentence of §118(1) of the AktG refers to two-way electronic communication - that is, the opportunity not only to observe the progress of the meeting but also to communicate with the other participants through electronic means of communication. Merely observing the meeting does not guarantee the shareholders the right to influence the decision-making process, and, regardless of how voting takes place, the legal literature emphasises that ensuring the right of virtual participation is essential and necessary for the exercise of shareholder rights. ${ }^{*} 35$ Unlike an observer of the meeting, all shareholders participating in the meeting through two-way

30 'Explanatory Memorandum to the Draft Act Amending the General Part of the Civil Code Act and Other Acts, 6.4.2020' (Tsiviilseadustiku üldosa seaduse ja teiste seaduste muutmise seadus. Eelnõu seletuskiri 6.04.2020).

31 'Gesetz zur Abmilderung der Folgen der COVID-19-Pandemie im Zivil-, Insolvenz- und Strafverfahrensrecht Vom 27. März 2020' [2020] Bundesgesetzblatt Jahrgang 2020, part I, no. 14, issued in Bonn on 27 March 2020.

32 See also: E Gottschalk and K Ulmer, 'Das Gesellschaftsrecht im Bann des Corona-Virus' [2020] Gesellschafts- und Wirtschaftsrecht 134 .

33 'Aktiengesetz vom 6. September 1965 (BGBl. I 1089), das zuletzt durch Artikel 9 des Gesetzes vom 17. Juli 2017’ (BGBl. I 2446), amended since.

34 L Beck, 'Aktuelles zur elektronischen Hauptversammlung' [2014] Rheinische Notar-Zeitschrift 160.

35 W Goette, M Habersack, and S Kalss, Münchener Kommentar zum AktG (4th edn, Verlag C.H. Beck München 2018) - Kubis, 'AktG', s 118, margin reference 80. 
communication can be deemed to be in attendance and their votes can be counted toward the quorum. ${ }^{*} 6$ Additionally, online participants must be able to exercise their shareholder rights in the same way they could if physically present at the meeting, except where the exercise of a certain right is precluded under the articles of association.

German legal literature nevertheless has so far noted that, in practice, electronic meetings as such have been held rather rarely while electronic voting when shareholders are physically present at the meeting is already relatively widespread. ${ }^{*} 37$ However, one can assume that holding virtual meetings will probably become more popular when taking into account that people's free movement is currently impeded.

In German legal literature, there is debate on the extent to which public limited company law, particularly provisions regulating the relationship between the company and shareholders, may be considered dispositive, but in comparison to Estonia the interpretations given there rely on significantly broader private autonomy. In line with the prevailing opinion, even though shareholders of a German public limited company cannot replace statutory rules with others, supplementing the existing rules is allowed. At the same time, supplementing is also understood as adding to the articles of association rules that develop the existing statutory rules such that the main essence and purpose of those rules remains unchanged. ${ }^{*} 8$ Thus, German regular law differs from existing Estonian law, firstly, in that it lays down certain rules on holding virtual meetings for all public limited companies and, secondly, because those rules may be modified through the articles of association. On the other hand, Estonia's new draft law can be considered very flexible as it allows all companies to specify the issues related to holding virtual meetings in their articles of association.

Comparison of Estonian company law with the law of some other European countries shows that, for example, United Kingdom law also enables general meetings of all public limited companies to be held electronically. Specifically, $\$ 360 A(1)$ of the Companies Act $2006^{*} 39$ allows holding and conducting a meeting in such a way that persons who are not present together at the same place may by electronic means attend and speak and vote at it. Under subsection (2) of the same section, in the case of a traded company, making use of electronic means for the purpose of enabling shareholders to participate in a general meeting may be done subject only to such requirements as are necessary to ensure the identification of those taking part and the security of the electronic communication, and proportionate to the achievement of those objectives. Thus, the law in the United Kingdom too is highly flexible and minimalist in terms of regulation.

Under Article 2:117a, clause 1 of the Dutch Civil Code, ${ }^{*}{ }^{\circ}$ the articles of association may entitle any shareholder to use electronic means of communication to participate in the general meeting, to address the general meeting, and to exercise their right to vote. Article 2:117a, clause 2 lays down, additionally, that, to participate in the meeting, the shareholder must be identified and must be able to obtain direct knowledge of the proceedings at the meeting and to exercise their right to vote. The same provision also lays down that the articles of association may provide that the shareholder is entitled to participate in the deliberations through electronic means of communication. Also important is the principle set out in clause 3 of the same article, that if the general meeting is going to be held electronically, this must be announced in the notice of convening the meeting. In sum, it should be concluded that Dutch law also already specifies broader electronic participation and Estonian law can catch up with regulatory competition only when the new draft law is adopted.

\subsection{The possibility of carrying out a fully virtual general meeting}

As a reason for which, allegedly, no general meeting can be fully virtual under German law, legal literature cites the argument that even if shareholders were to be given the opportunity to participate remotely in a general meeting through electronic means of communication, members of the management board

36 Ibid, Kubis, 'AktG', s 118, margin reference 80.

37 G Spindler and E Stilz, Kommentar zum Aktiengesetz (4th edn, Verlag C.H. Beck 2019) - Hefendehl, 'AktG', s 402, margin reference 17.

38 O H Behrends, 'Einberufung der Hauptversammlung gem. § 121 IV AktG (mittels eingeschriebenem Brief) trotz abweichender Satzungsbestimmung' [2000] Neue Zeitschrift für Gesellschaftsrecht 579.

39 Companies Act 2006. https://www.legislation.gov.uk/ukpga/2006/46/contents.

40 Dutch Civil Code. http://www.dutchcivillaw.com/civilcodebook022.htm. 
and the supervisory board usually must attend the meeting. ${ }^{*}{ }^{41}$ Thus, it has been found that under current law a general meeting of shareholders can never be held fully electronically. ${ }^{*}{ }^{42}$ The German temporary legislation ${ }^{*} 43$ shows that the physical presence of the members of the management and supervisory board is in fact an impediment to holding a fully electronic meeting. Estonian law, on the other hand, does not require members of the management board or the supervisory board to attend the meeting. Only the optional principles of good corporate governance for listed public companies ${ }^{*} 44$ set out that members of the management board; the chair of the supervisory board; and, if possible, also members of the supervisory board and at least one of the auditors should attend the general meeting. Furthermore, the author is of the opinion that even Estonia's existing law, not to mention the proposed amendments, allows the interpretation that the presence of the management and the supervisory board members, if needed, may be virtual and it is possible to hold a meeting such that all participants are in separate locations.

\section{Problems in relation to electronic participation in a general meeting}

\subsection{Verification of participation and technical problems}

A precondition for holding a meeting is that the right persons - namely shareholders - participate. German legal literature notes that in the event of electronic participation, just as in the event of physical attendance at a meeting, identification of shareholders must be ensured. In this regard, it has been recommended to use, for example, logging in to the system by using a PIN code for this purpose (i.e., using a so-called login mask). ${ }^{*} 45$ This is certainly one option and probably the most secure one. However, setting up a special environment can be too burdensome, especially for smaller public companies who know their shareholders and therefore can identify them easily by using a Web-camera. The author of the article is of the opinion that public companies with fewer than, for example, 20 shareholders can very well organise meetings held via Skype, MS Teams, or other (similar) applications.

Addressing the problems of a virtual meeting, German legal literature cites the argument that even if the articles of association lay down the possibility of electronic participation, it still remains unclear what can be deemed participation within the meaning of the law. First and foremost, the question arises of how a shareholder's participation is to be verified. Secondly, it has been found that a shareholder participating in a meeting through electronic means of communication might not, in a situation wherein the meeting adopts a resolution and electronic voting takes place also, be certain whether it was indeed the decision that was displayed as that shareholder's particular vote being counted as their vote in reality. In the event of electronic participation, the risk of technical problems always exists too - transmission disturbances might either partly or fully prevent a shareholder from receiving all the information that they need to exercise their right to vote. ${ }^{*} 46$ This could be a real problem, since current experience of working from a distance in Estonia has already shown that, if a successful meeting is to be held, one needs good Internet access and the relevant technical equipment.

Holding a virtual meeting must also take into account that the technical possibilities available to the company and to its shareholders must be mutually compatible. ${ }^{*} 7$ Where this is not so, or where only some shareholders have the technical prerequisites for participation in the meeting, the requirements for holding a virtual meeting have not been fulfilled.

$41 \quad$ M Schüppen and B Schaub, Münchener Anwaltshandbuch. Aktienrecht (3rd edn, 2018) - Bohnet, s 26, 'Vorbereitung der Hauptversammlung', margin reference 32. The requirement of notarial authentication of a resolution of the general meeting arises from $\$ 130(1)$ of the AktG.

42 L Beck (n 34) 160.

43 See: art 2, s 1(2) of COVInsAG.

44 'Corporate Governance Recommendations’ https://www.fi.ee/failid/HYT_eng.pdf. The above principles are laid down in Article 1.3.2.

45 U Hüffer and J Koch (n 16) - Koch, 'AktG', s 118, margin reference 12.

$46 \quad$ L Beck (n 34) 164.

47 Reference to this has also been made, for example, in U.S. legal literature (see: A van der Krans (n 17) 35). 
Another shortcoming of an electronic meeting that has been pointed out is the lack of an atmosphere conducive to debate in an electronic meeting: in a situation wherein the management board and shareholders are not physically present at the same location, it is easier to express criticism (non-constructive included) while it is more difficult to exchange views with other shareholders. ${ }^{*} 8$ The author is of the opinion that this should not be a big problem at least for smaller companies, and one can argue that holding a meeting electronically might even contribute to a more constructive atmosphere.

\subsection{The place of the general meeting in the case of an electronic meeting}

Under §295 of the Estonian Commercial Code, a general meeting is to be held at the registered office of the public limited company unless otherwise prescribed by the articles of association. In the opinion of the author of the present article, the above-mentioned provision neither restricts the right to hold the meeting virtually nor obliges the participants to be physically at the location of the company. The aim behind this regulation is to protect shareholders from a situation wherein the management board convenes the meeting in some unexpected place. Therefore, $\$ 295$ of the Commercial Code should be interpreted in such a manner that it applies only to those meetings held physically.

German legal literature has debated whether, in a situation in which this is not specifically laid down in the articles of association, a general meeting of shareholders could also be held such that the participants are not simultaneously at the same location but in different locations, where the various meeting sites are connected to each other and everyone can hear and see everything taking place at the meeting. In this regard, an opinion has been expressed that such an interpretation is conceivable in itself, but at the same time doubts have been raised as to whether this would be affirmed by judicial practice should a dispute arise pertaining to the validity of a resolution of a general meeting. The main reason for doubt is that under the wording of the law the meeting is to take place at a 'single location'. ${ }^{*} 49$ In the opinion of this author, the latter misgiving appears not to be justified, since the provisions of the AktG do not directly and unequivocally stipulate that it should definitely be one location. For example, §121(3) of the AktG stipulates that the notice of the shareholders' general meeting must state the place of the meeting, but the mere fact that the word 'place' in this provision is in the singular does not imply that the provision could not be interpreted so as to allow the meeting to be held, for instance, simultaneously in several locations via electronic access.

Furthermore, Estonian case-law has dealt with a dispute involving whether a general meeting could be held at multiple times and in multiple locations, in such a way that the meeting participants cannot observe what happens at the same time in other places where the meeting is being held. The Supreme Court adjudicated on this kind of dispute in a case involving a garage association ${ }^{*} 50$ and held that if the association has decided that certain issues are to be resolved at a general meeting, the general meeting must take place simultaneously for all members of the association. The Supreme Court noted that this does not necessarily mean that all the members have to be simultaneously in the same place but stressed, first and foremost, that the meeting must be accessible in time and space for all members and that such accessibility may also be created via electronic means (e.g., Skype). ${ }^{*}{ }^{1}$

In the same case, the Supreme Court formulated the purpose of a general meeting of non-profit associations thus: to enable members to jointly exercise their membership rights, form opinions based on debate of issues on the agenda together with other members, and vote in accordance with one's will developed in the knowledge of all the circumstances and opinions. The Supreme Court noted that holding a meeting with a subset of the membership at a different time fails to ensure, inter alia, that the meetings are identical; if members vote at a different time and place, no-one can be sure what was said at the previous part-meetings or what will be said at the next ones, or how draft resolutions are explained at other part-meetings. ${ }^{*} 2$

$48 \quad$ L Beck (n 34) 165.

49 M Schüppen and B Schaub (n 41) - Bohnet, s 26, 'Vorbereitung der Hauptversammlung', margin reference 32.

50 In this context, in the absence of special rules, a garage association as a form of apartment association is subject to rules applicable to non-profit associations laid down in the Non-profit Associations Act (RT I 1996, 42, 811; 19 March 2019, 24).

51 Supreme Court Civil Chamber order 3-2-1-89-16, para 9.

$52 \quad$ Ibid, para 9. 
One can only agree with this position, and, in the opinion of this author, both the purpose of holding a meeting and the requirement of a simultaneous meeting are the same for limited companies, including public limited companies, also extending to when a meeting is held virtually. Provisions enabling electronic participation may not prevent shareholders from jointly debating the issues on the agenda and developing their opinions in the course of debate and reaching informed decisions. It should be kept in mind that, in addition to the possibility of a resolution being passed at a general meeting, a public limited company has the option of adopting a resolution in writing (\$305(1) and (2) of the Commercial Code), ${ }^{*} 33$ but once a decision has already been made to hold a general meeting to pass resolutions, the rights of shareholders should be safeguarded to the greatest possible extent, with cases of an electronic virtual meeting included. This is not so if a meeting is held at several times and in different places.

\subsection{Minutes of a virtual general meeting and the role of a notary at a general meeting}

Also, in German legal literature, it has been noted that, since the minutes of a general meeting are the most important means of documenting the conduct of the meeting, the requirements for keeping the minutes and for their notarial authentication require that, even if shareholders are allowed to participate in a meeting remotely, a 'physical' meeting always take place somewhere with the attendance of a notary and members of the managing bodies. The possibility should be ruled out of the person keeping the minutes becoming at some point, for whatever reason, no longer able to observe the meeting and document its conduct, but this is arguably not possible in the case of fully electronic participation. ${ }^{*} 54$

Since in Germany the requirement of notarial authentication of the minutes of a general meeting has been laid down for all public limited companies, the question arises, inter alia, of what additional duties are imposed on a notary in the event of enabling electronic participation in a general meeting. The question is also relevant in the context of Estonian law, since, even though the Commercial Code does not impose the requirement of notarial authentication of all minutes of general meetings, in certain cases the minutes do need to be notarised in line with the statutory requirement, ${ }^{*} 55$ and additionally the law allows shareholders or other persons so entitled to request notarial authentication of the minutes. In the German legal literature, the role of a notary in virtual meetings is considered important also because, whereas at ordinary general meetings the shareholders themselves can observe how resolutions are passed, in the case of electronic participation, in contrast, this might not be possible for shareholders, and it is the notary who sees directly how and whether resolutions reach the number of votes needed for passing. ${ }^{*}{ }^{6}$ However, this problem probably concerns only public companies with a large number of shareholders who participate and vote through a special login system. When, for instance, Skype or MS Teams is used, the decision-making can be arranged in a manner allowing everyone to observe the decision-making process.

German legal literature notes that, in a situation wherein the articles of association enable shareholders to participate in a meeting via electronic means of communication, the duty of the so-called plausibility check (Plausibilitätskonrolle) is imposed on the notary. Specifically, the notary must be satisfied that the communication technology made available by the company is reliable and must verify whether the server and other technical solutions used by the company are dependable and have sufficient capacity. However, since, as a rule, a notary does not have the relevant specialist knowledge, the requirements imposed on a notary should not be excessively stringent, and the company should enable the notary to use the assistance of people with specialist knowledge. ${ }^{* 57}$

53 In that case, the precondition for passing a resolution is that it be formulated in writing and that all the shareholders sign the resolution.

$54 \quad$ L Beck (n 34) 167.

55 Under §304(7) of the Commercial Code, this is so if a resolution of the general meeting is the basis for election or removal of a member of the supervisory board, or for amending the articles of association with regard to the supervisory board.

56 K-J Fassbender, 'Die Hauptversammlung der Aktiengesellschaft aus notarieller Sicht' [2009] Rheinische Notar-Zeitschrift 457. In the opinion of the present author, this position is primarily relevant for cases where electronic voting takes place in addition to electronic participation.

57 Ibid, 456. 
The Estonian Notarisation Act ${ }^{*} 8$ is just like the German Notarisation Act ${ }^{*} 59$ in not laying down special rules for instances wherein a general meeting of a legal person (public limited companies included) takes place such that shareholders participate in it electronically. However, $\S 1\left(3^{1}\right)$ of the Estonian Notarisation Act enables most notarial acts to be performed by remote authentication ${ }^{* 60}$, and, under $\S 12^{1}\left(6^{1}\right)$ of the Notarial Regulations ${ }^{*} 61$, also remote authentication of the minutes of a general meeting is possible. ${ }^{* 62}$

In line with the first sentence of \$36(1) of the Notarisation Act, in the event of authentication of a resolution of a general meeting of a public limited company, a notary must verify the quorum of the meeting and the identity and active legal capacity of the chair and the secretary of the meeting. The notary must indicate the results of this verification, the agenda of the meeting, the content of the resolutions adopted, the results of voting, and dissenting opinions regarding the resolution. Under \$36(3) of the Notarisation Act, the chair of the meeting is liable for the correctness of the list of participants, and the person who holds the voting is liable for the correctness of the record of voting. Both of them must sign the list or record in the presence of a notary to confirm correctness. The list of parties or the record of voting must be appended to the notarial instrument. A notary must indicate any doubts pertaining to the quorum, legality of resolutions, conformity of the list of participants or record of voting with the membership of the relevant body, and authority of representatives, in a notarial instrument prepared with regard to the minutes (\$36(4) Notarisation Act). On that basis, under Estonian law, identification of participants in the meeting (including meetings held via electronic means of communication) is not directly the duty of a notary; however, it cannot be claimed that a notary should not have any role in at least raising issues with regard to the quorum or the correctness of voting results. Thus, in Estonia, problems similar to those with German law can (at least hypothetically) arise, and the role of the notary in authenticating the minutes of an electronic meeting would probably need to be regulated more precisely.

\subsection{The effect of technical problems on resolutions of a general meeting}

As for technical problems that may occur at an electronic general meeting, in Germany they do not, as a rule, constitute circumstances enabling a claim for annulment of a resolution. ${ }^{* 63}$ Additionally, legal literature has deemed it questionable whether a technical malfunction can even be interpreted as violation of someone's rights. ${ }^{* 64}$ First of all, it has been emphasised that no violation can be attributed to a public limited company where the technical malfunction falls within the sphere of influence of a shareholder themselves (for example, they are disconnected from the Internet during the meeting). ${ }^{*} 65$

However, in the opinion of the present author, the situation may be different where the technical malfunction is so considerable as to result in significant interference with participation. In that case, it should nevertheless be possible to contest a resolution that, according to the minutes, was deemed as adopted. The law does not directly lay down that opportunity, because a resolution of a general meeting may only be annulled if it contravenes the law or the articles of association. ${ }^{* 66}$ However, a conflict with the articles of association (in the sense employed in the law in force at the time of writing) or with the law (in the sense of

58 Notarisation Act [Tõestamisseadus] - RT I 2001, 93, 564; RT I, 22 February 2019, 3.

59 'Beurkundungsgesetz vom 28. August 1969 (BGBl. I 1513), das zuletzt durch Artikel 13 des Gesetzes vom 30. November 2019 (BGBl. I 1924) geändert worden ist', amended since.

60 Under §13(7) of the Notarisation Act, in the case of remote authentication, the necessary acts are carried out via a video bridge enabling a person and their intention to be identified, subject to the specifications derived from the manner of authentication, and the act is deemed to have been performed in the presence of the notary.

61 Notarial Regulations [Notariaadimäärustik] - RTL 2009, 51, 751; RT I 3 April 2020, 20.

62 In fact, only marriage and divorce cannot be authenticated remotely.

63 Under §243(3), clause 1 of the AktG, no claim for annulment of a resolution of a general meeting may be brought where the violation was caused by a technical malfunction related to electronic participation in the general meeting, unless the company can be accused of gross negligence or intent.

64 U Hüffer and J Koch (n 16) - Koch, 'AktG', s 118, margin reference 14.

65 L Beck (n 34) 165.

66 Under §178(1) of the Commercial Code, on the basis of an action filed against a private limited company, a court may annul a resolution of shareholders contravening the law or the articles of association. 
the proposed future regulations) may be present if the violation during the conducting of the meeting was due to infringement of requirements set on holding of virtual meetings. ${ }^{* 67}$

\subsection{Equal treatment of shareholders and ensuring shareholder rights at an electronic general meeting}

There are two aspects of equal treatment of shareholders with regard to virtual meetings. Firstly, one can ask whether fully virtual attendance may be forced on shareholders.

As regards the issue of whether a complete transfer to electronic meetings would be conceivable, doubts have been expressed in German legal literature noting that, despite the widespread use of electronic means of communication and various technical possibilities, some shareholders always, for some reason, do not want to or cannot use modern means of communication, so such shareholders would be sidelined in the case of a fully electronic meeting. It is argued that such sidelining cannot even be justified by the fact that, in itself, deciding on the threshold for electronic participation is within the competence of shareholders and, thereby, in a way, the shareholders themselves can decide how to regulate electronic participation through the articles of association. The argument is that establishing rules in the articles of association is under the control of majority shareholders, while those shareholders who do not wish to utilise electronic participation are normally in the minority and therefore would never have their views reflected in the articles of association. Consequently, it is argued, such strong interference with the membership rights of shareholders is not justified without the articles of association simultaneously laying down appropriate compensation. ${ }^{* 68}$ However, it is difficult to imagine what that compensation might look like. In German legal literature, this situation has been compared to the one in which profit is transferred within a group of companies, to another company in the group under a profit distribution agreement, and minority shareholders of the original profit-earning company are thereby deprived of profit. In that situation, the law entitles the minority to compensation. ${ }^{*}{ }^{69}$ In Estonian law, however, fair compensation is provided only where equity participation is lost completely, ${ }^{*} 70$ so those provisions are not of use even on the basis of analogy, since someone with no access to an electronic meeting has not lost their equity participation. That said, the law itself could actually lay down provisions under which a shareholder who does not agree with electronic communication being forced upon them is entitled to require either the company or other shareholders to acquire their equity participation against fair compensation.

The second problem (one of the most debated topics in German legal literature) in this area is the extent to which the shareholder rights may differ between those participating physically and those participating in the same general meeting via electronic means.

The AktG in itself enables articles of association to establish very different opportunities for participation in a general meeting and for the exercise of related rights; for example, the articles of association may prescribe that the same rights enjoyed by physical participants are ensured for those participating in a meeting via electronic means of communication, but it is also possible to lay down that only some rights are ensured. Moreover, the exercise of certain rights may be excluded in the event of electronic participation. ${ }^{*} 71$

Nonetheless, whether under German law online participation may influence shareholder rights related to participation in a general meeting is debatable. Disputes have been caused by, for example, the issue of whether the right of shareholders to contest resolutions of the general meeting could differ with the manner

67 Apparently, no issue arises as to nullity of a resolution of the general meeting since the resolution could be void for procedural reasons only if the procedure for calling the general meeting that passed the resolution was violated (Commercial Code, $\mathrm{s}$ $\left.301^{1}(1), \mathrm{cl} 4\right)$.

68 L Beck (n 34) 166.

69 Under $\S 304$ of the AktG, adequate compensation must be paid to shareholders who are deprived of profit under a profit transfer agreement (Gewinnabführungsvertrag) entered into by the company. Estonian company law regulates relationships in a group of companies only to a limited extent, and no such provision exists in the law.

70 For example, the obligation to pay fair compensation is laid down in $\S 363^{1}(1)$ of the Commercial Code for a situation wherein a majority shareholder takes over shares owned by minority shareholders. Section $233^{3}(1)$ of the Commercial Code also entitles a shareholder to transfer their shares and receive fair compensation in return where the person maintaining the share register is replaced and the shareholder does not agree with the replacement.

71 U Hüffer and J Koch (n 16) - Koch, 'AktG', s 118, margin reference 13. 
of participation in a meeting, ${ }^{*} 72$ along with the issue of whether the articles of association may deprive online participants of the right to file objections to resolutions passed at the meeting. ${ }^{*} 73$ On one hand, it has been found that, as a rule, such a restriction should not be possible. ${ }^{*} 44$ However, on the other hand, the view has been expressed that the freedom for the articles of association is extensive, enabling the company itself to decide whether to afford online shareholders all or only some of the rights connected with a general meeting. On that basis, it has been found in some legal literature that it is entirely conceivable that online participants may have, for instance, the right to ask questions while not having the right to receive answers on the spot, or for shareholders participating in a meeting via electronic means to enjoy the right to vote but lack the right to file objections to resolutions. ${ }^{*} 75 \mathrm{In}$ sum, the predominant view is that, in principle, the law does not preclude putting online participants and other shareholders in two, mutually distinct situations, ${ }^{*}{ }^{76}$ nor does it preclude the articles of association from providing advantages to shareholders who are physically present at a meeting. ${ }^{*} 77$ However, in line with the predominant view in German legal literature, shareholders participating in a meeting electronically should have the same right to contest resolutions as shareholders who are physically present at the meeting, on the precondition that the articles of association have not unequivocally deprived online participants of the right of contestation. ${ }^{*} 78$

In the opinion of this author, the interpretation that the articles of association may deprive a shareholder who is electronically participating in a meeting of the right to contest resolutions is highly questionable, as this may contravene the principle of equal treatment of shareholders. ${ }^{*} 79$ The claim that there is no conflict with the principle of equal treatment could be justified only by the argument that since laying down rules on the exercise of electronic rights has been left for the articles of association to regulate, no equal underlying circumstances exist but special treatment has been agreed upon by the shareholders themselves in the articles of association. However, that justification is not very convincing, since the freedom to shape the articles of association is under majority shareholders' control.

Given that, according to the Estonian legal literature ${ }^{*} 80$, the rules regulating the forms of participation in a meeting are rather imperative in nature, it is apparently impossible to agree in the articles of association of an Estonian public company that different rights of participation in meetings are assured to shareholders on the basis of whether they participate electronically or instead are physically present. Excluding the opportunity to object to a resolution should definitely not be admissible, since the subsequent opportunity to contest the resolution depends on it. ${ }^{*} 1$

\section{Conclusion}

Prior to adoption of the new regulation that entered into force on 24 May 2020, there was ongoing discussion of whether virtual shareholder meetings are allowed for other than listed companies in Estonia. For this, the opportunity of electronic participation had to be laid down in the articles of association. On the other hand, Estonia's new regulation ensures an opportunity to hold digital meetings for all types of companies, irrespective of whether the articles of association foresee this option. For that, the General Part of

72 First of all, the issue of filing a claim for annulment of a resolution may be raised under §243(1) of the AktG, which lays down that annulment of a resolution of a general meeting may be sought where the resolution is in violation of the law or of the articles of association; the same right of contestation is given to shareholders of a public limited company in Estonia under $\S 301(1)$ of the Commercial Code.

73 Under §245, clause 1 of the AktG and §301(3) of the Commercial Code, only a shareholder who participated in the general meeting and raised an objection to the resolution, also having it recorded in the minutes, may seek annulment of the resolution.

74 U Hüffer, J Koch (n 16) - Koch, 'AktG', s 118, margin reference 13.

75 W Hölters (ed), Aktiengesetz. Kommentar (3rd edn, Verlag C.H. Beck / Verlag Franz Vahlen München 2017) - Drinhausen, 'AktG', s 118, margin reference 16.

76 W Goette, M Habersack, and S Kalss (n 35) - Kubis, 'AktG', s 118, margin reference 82.

77 L Beck (n 34) 160.

78 U Hüffer and J Koch (n 16) - Koch, 'AktG', s 118, margin reference 14.

79 The AktG lays down the principle of equal treatment of shareholders in §53a, and the equivalent rule in the Commercial Code is set out in $\$ 272$. Both rules stipulate that shareholders must be treated equally in equal circumstances.

80 See, for instance: P Varul et al. (n 25) - P Varul, s 5, comment 3.

81 Under §302(3) of the Commercial Code, a shareholder who participated in the general meeting may seek annulment of the resolution only if they had their objection to the resolution recorded in the minutes of the general meeting. 
the Civil Code Act was supplemented with a provision according to which every member of a body of a legal person may attend the meeting of the body and exercise his or her rights without being physically present by electronic means that allow the member to observe the meeting, to speak, and to vote unless the articles of association provide otherwise. Articles of associations of public companies may foresee special rules for holding an electronic meeting, contingent upon the procedures provided ensuring the security and reliability of the identification of shareholders and being proportionate. For smaller companies, it is therefore possible (and legal) to hold meetings via Skype or other, similar applications. One can only agree with the remark of Estonian legal scholars that sometimes a global crisis is needed for seeing what is obvious. ${ }^{*} 2$

Although electronic participation seems a convenient and favourable opportunity, it also involves several legal and technical problems. Among these problems is authentication - that is, how to verify the participation of shareholders in big public companies that may have hundreds of shareholders. Another problem is the lack of clarity related to the issue of legal consequences that may arise in the event of technical problems. Also, the extent to which electronic participation may be forced on shareholders is arguable, as is whether minority shareholders should be entitled to require the company or the majority shareholders to acquire their shares against fair compensation if, for some reason, electronic participation is not suitable for them.

The present author supports the view that where an electronic general meeting is held, shareholders participating in the meeting electronically should be guaranteed the same rights as enjoyed by those physically attending the meeting. Even though an opinion has been expressed in German legal literature that deprivation of certain rights is permissible only through laying down restrictions in the company's articles of association, one cannot agree with this position, since, at least as a rule, a shareholder's rights may only be restricted with their consent and not through articles of association adopted by a majority. 